\title{
ON THE ORIGIN OF THE NAME DINARA
}

\author{
VPRAŠANJE IZVORA IMENA DINARA
}

\author{
Andrej KRANJC ${ }^{1}$ \& Luiz Eduardo PANISSET TRAVASSOS ${ }^{2}$
}

\begin{abstract}
UDC 81'373.21(234.422.1)

Andrej Kranjc \& Luiz Eduardo Panisset Travassos: On the origin of the name Dinara

This short paper on the origin of the name Dinara based on literature is in fact an open question and a challenge for future researchers. The authors are relatively well acquainted with the Western part of Dinaric karst and corresponding "western" literature and from this point of view they tried to find out where and when appeared the name Dinara for the mountain as well as for the whole Dinaric chain as we call it nowadays. Based on older literature and maps they found out that the name $\mathrm{Di}$ nara appeared in the $16^{\text {th }}$ century in a novel, not in a professional work, while in the $17^{\text {th }}$ (Evliya Çelebi) and during the $18^{\text {th }}$ centuries it became largely used by authors describing Balkans (Fortis 1774, Hacquet 1785). During the $19^{\text {th }}$ century it was a generally adopted name, often as Dinaric Alps. Authors make an appeal to researchers whose topic is Dinaric karst to pay attention to this question; especially to older publications which are not generally known and accessible.
\end{abstract}

Key words: Dinara, Dinaric Mountains, origin of name.
Izvleček

UDK 81'373.21(234.422.1)

Andrej Kranjc \& Luiz Eduardo Panisset Travassos: Vprašanje izvora imena Dinara

Pričujoči kratki prispevek na podlagi pregledane literature predstavlja nerešeno vprašanje izvora imena Dinara, kar je lahko tudi izziv za prihodnje raziskovalce. Kot poznavalca predvsem zahodnega dela Dinarskega krasa in ustrezne "zahodne» literature sta avtorja poskušala ugotoviti, od kod izvira oziroma od kdaj se pojavlja ime Dinara za samo goro s tem imenom pa tudi za celotno Dinarsko gorstvo, kot ga pojmujemo danes. $\mathrm{Na}$ podlagi starejše literature in zemljevidov ugotavljata, da se ime Dinara pojavi v 16. stol. v romanu, ne v strokovni publikaciji, v 17. (Evliya Çelebi) in 18. stol. ga že pogosteje uporabljajo opisovalci tega dela Balkana (Fortis 1774, Hacquet 1785), v 19. stol. pa je že splošno priznano ime, pogosto kot Dinarske Alpe. Avtorja pozivata raziskovalce, ki se ukvarjajo z Dinarskim krasom, naj posvetijo nekaj pozornosti temu vprašanju, posebno o starejši literaturi, ki ni splošno znana in dostopna.

Ključne besede: Dinara, Dinarsko gorstvo, izvor imena.

\section{INTRODUCTION}

Among mountains of Western Balkans the Mountain Dinara is the most impressive. It lies not far away from the Adriatic Sea and its ridge, over $50 \mathrm{~km}$ long and nearly $2000 \mathrm{~m}$ high, is well visible from both sides, from the coast and from the land side. Nowadays it is the border between Bosnia and Herzegovina and Croatia. Dinara is a very impressive typical karst mountain of carbonate rocks. That has to be the reason of its importance: after it the whole range is called Dinaric Mountains, geologically Dinaric System and Dinarides,

${ }^{1}$ Slovenian Academy of Sciences and Arts, Novi trg 3, 1000 Ljubljana, Slovenia, e-mail:makranjc@siol.net

${ }^{2}$ Graduate Program in Geography - Pontifícia Universidade Católica de Minas Gerais (PUC Minas) Av. Itaú 505 - Bairro Dom Bosco - Belo Horizonte - Brasil, e-mail: luizepanisset@gmail.com

Received/Prejeto: 19.01 .2018 


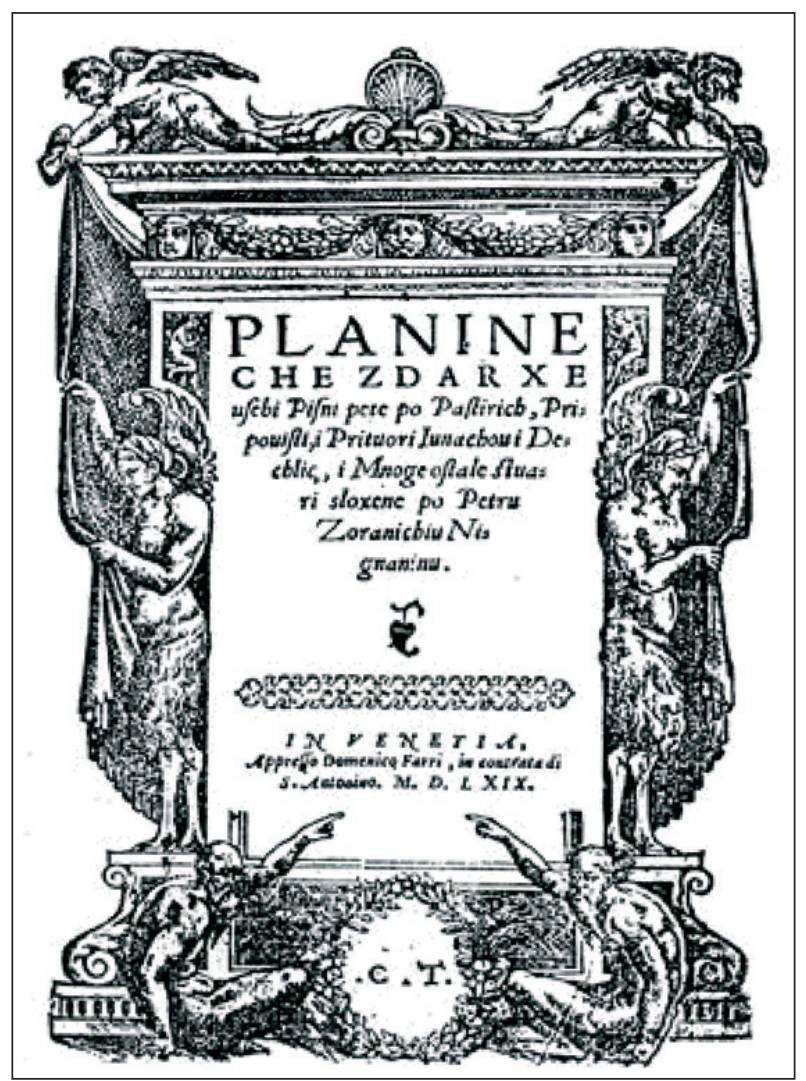

Fig. 1: Title page of Zoranićs book (1569), where the name Dinara is mentioned for the first time.

Dinaric Karst, and the direction NW - SE is called Dinaric direction. It would be interesting to know the origin of the name, where did it come from, when it

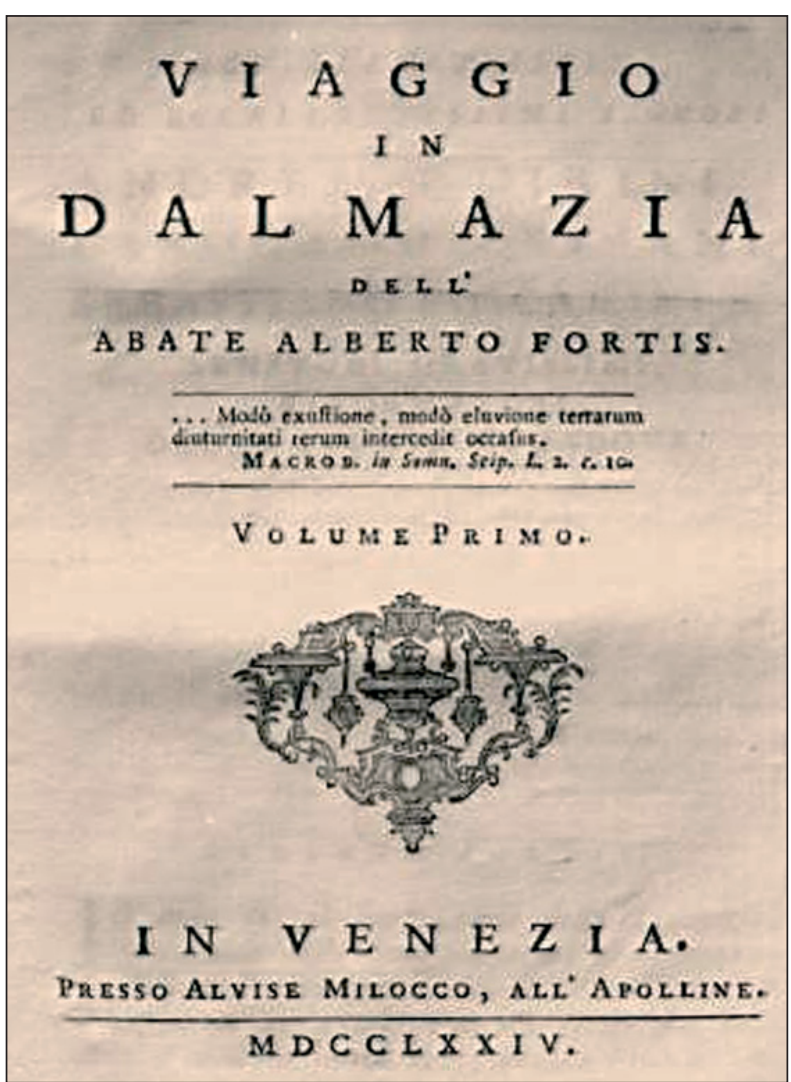

Fig. 2: Title page of Fortis' book Travel to Dalmatia (1774).

started to spread to the whole mountain range, to the whole karst of the Western Balkans. Preliminary results are shown in this paper.

\section{FIRST MENTIONS AND LOCATIONS ON MAPS OF THE MOUNTAIN NOWADAYS CALLED DINARA}

It is surprising that for the first time the name Dinara is mentioned in the first novel written in Croatian language and printed in 1569, with the title Planine (Mountains). There stood: "I am Krka, the daughter of Dinara, the fairy and the landlady of this river" (Zoranić 1988). Krka is the karst river springing at the foot of Dinara Mt.. Up to now this is the first known written record of the name Dinara.

In some serious etymological dictionaries, encyclopaedias or lexicons we did not find the explanation of the origin that is the etymology of the name Dinara (Cvitanović 2002; Rogić 1956; Skok 1971). Already in early sources appeared the mountain called Dinara today. The geographer Strabo (63 BC - $24 \mathrm{AD}$ ) wrote in his Geography (Book VII, Chapter 5, Section 2): “The mountain Adrion divides Dalmatia into two parts, one of which is on the sea, the other forms the opposite side of the mountain." (Anon. 1903). It seems sure that by the Adrion is meant the nowadays Dinara Mt. How large was the territory of Adrion is difficult to say because we do not know what exactly meant "Dalmatia" for Strabo? It is possible that Adrion was what is today the whole system of Dinaric Mountains and not just the Dinara Mountain (Roksandić 1999-2000). During the Iron Age and in the time of the Roman Empire, the Illyrian tribe of Dindari lived East of Dinara. The tribe's name somehow resembles the name of the mountain Dinara (Šišić 2004). De Administrando Imperio ("On the Governance of the Empire") is the Latin title of a Greek work written by the 
10th-century Eastern Roman Emperor Constantine VII. It is a domestic and foreign policy manual for the use of Constantine's son and successor, the Emperor Romanos II. For the history of Croatians and Southern Slavs this is the most important written document (Ostrogorski 1969, Džino 2010, Stih 2012). On the map called Tabula Peutingeriana, the copy of a Roman map approximately from the same time of Strabo writing, there is a mountain range marked in the land NW of Spalato (Split). By its position and size it could be Dinara Mt., but no name of it is mentioned (Talbert 2010). The map of Ioan. Sambucus of 1572 showed in the circle where springs of rivers Una, Zrmanja, Krka, and Cetina are situated, the central mountain range, where more ranges merged. It has NW-SE direction and is without doubt Dinara, but no name is written even there (Roksandić 1999-2000). In 1590 A. Ortelius published the map of Pannonia and Il- lyria where there is marked a mountain approximately on the place of the Dinara with the name Albius et Albinus mons". Further towards NW there is the settlement with the name Dindarij. It is difficult to say if this name has something common with the actual name of the mountain. Similar as the map of Sambucus the map of Bussemacher (1592) shows the sources of the mentioned rivers around a mountain ridge without the name. But more at the foot of the mountain there are places Xuonigrat, Dinario, and Cetina. Just Dinario is in the centre of the springs circle. But it is not clear what this Dinario means, although it appears on several old maps. On the maps of Du Val (1663) and Giacomo Cantelli da Vignola (1690) there are similar situations as on the Sambucus' and Bussemacher's maps, the situation of the mountain which has to be Dinara is well shown, but the name Dinara does not appear (Roksandić 1999-2000).

\section{DINARA ON MAPS AFTER 1700}

After the so called Treaty of Karlowitz (1699) the Triplex Confinum (Triple border), these are new borders among Austria, Venice and Ottoman Empire had to be traced. They have to be mapped and the first of maps is the set "Mappa geographico limitanea ..." kept in the War Archives (Kriegsarchiv) in Vienna. The most important

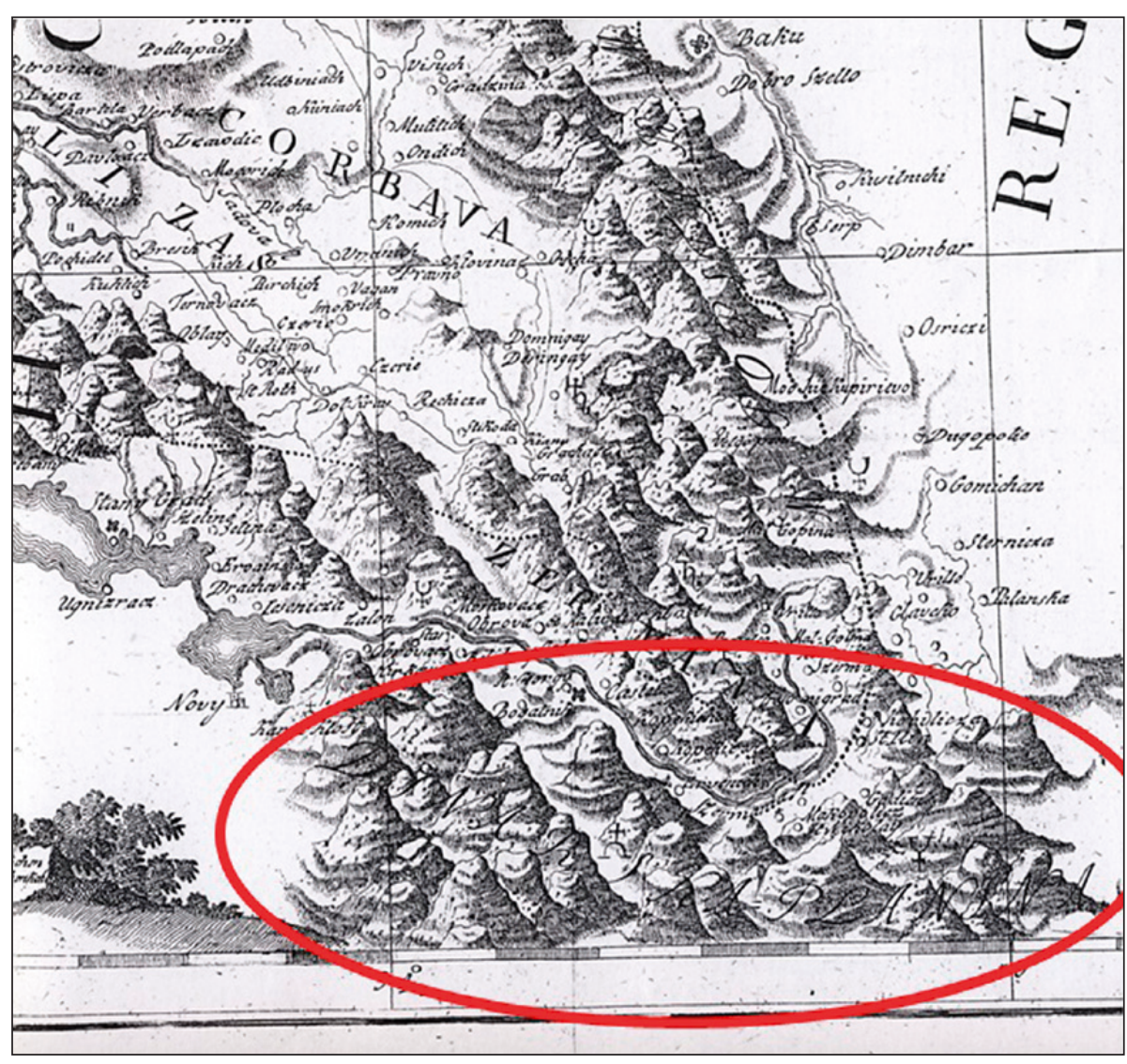

Fig. 3: Extract of the Hacquet's map "Continuatio Mappae Litho Hydrographicae Nationis Slavicae" (1787) where the inscription "Dinarska Planina" is well seen (Hacquet 1789). 
for us is the section XXIV (Confinium Turco-Venetor) where the name Dinara appeared. But on this as well as on later maps, the name Dinara is not the name for the mountain or mountain ridge as a whole, but just the name of one of the summits of what we call Dinara Mountain today. Such is an example of the map "Plan von Dalmatien" of F. Portner drawn from 1791 to 1797. French administration ordered also the adequate map:
"Carte militaire et marine de la Dalmatie..." (1806) and the name Dinara appeared on it, but again just as one of summits (Roksandić 1999-2000). On the other side, the excellent map of Illyrian Provinces "Carte des Provinces Illyriennes" (Palma 1812), the "Feuille IX" shows clearly the relief, there are many villages and also names of karst springs (Vrillo Cetina for example) but no mountain or any other topographic names.

\section{DINARA IN TRAVEL REPORTS AND BOOKS}

Mountain Dinara is mentioned in Evliya Çelebi's "The Travel Diary" (Sijāhatnāme), the manuscript of 10 volumes which have been found till at the end of the $19^{\text {th }}$ century in Pertev-Pasha Library at Istanbul. Evliya Çelebi' (his full name was Evliyā ibn Derwish Mehmed Zilli, 1611-1682) was primarily a traveller. The part of his diary related to the Balkans, was translated into Serbo-Croatian and Bosnian languages and more editions were published up to now. In the Chapter "Our departure from Livanjsko polje to plun- der towns of Zadar and Šibenik..." he mentioned "The River Cetina... which have springs on the Eastern and Southern sides of the Mountain Dinara" (Evlija 1996). We are sorry to say that we could not consult the original in Turkish language to see how the name Dinara is written. It can be in some other form and as the translator knew it is Dinara, he wrote the actual name. In fact, Evliya's orthography of geographical names is different from actual one, probably he had difficulties to write down unusual (for the

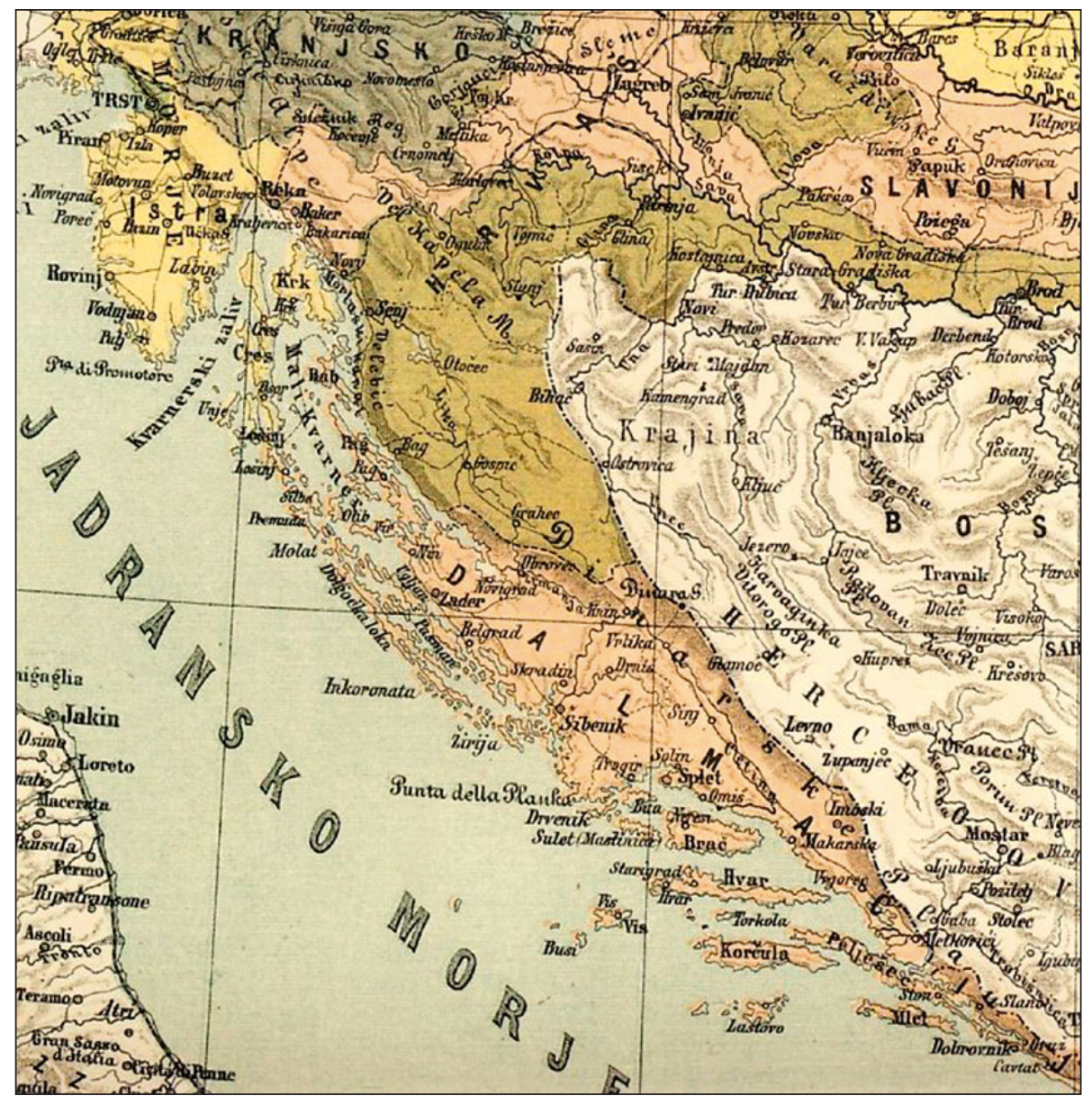

Fig. 4: The map of Balkans from the first Slovenian atlas, the Atlant (1869). 
Turk) names or he simply made a mistake. So he wrote the name of the Mountain Zmijanja as "Izmiyan", the river Cetina is "Četine", Varcar-Vakuf, "Vrčal Vakfi" and Slavonija "Islavoniya" just to mention some examples.

In 1774, A. Fortis (1741-1803) published in Venice the book Viaggio in Dalmazia (Travel in Dalmatia) (Fortis 2004). He belonged to Augustine Order and was a naturalist. He travelled alone or with rich people who were interested in these, for Western and Middle Europe quite unknown and exotic lands of Western Balkans. He published few books and many papers, but for the part along the Eastern coast of the Adriatic his Travel in Dalmatia is the most important. In this book the name of the Mountain Dinara is mentioned five times: Dinara as a divide (barrier) of some poljes, lithology of its summit (marble); and two times he is correcting mistakes of earlier authors regarding the part around Dinara Mountain. For Fortis, it seems, the name Dinara is just usual and common name.

In the years 1765 - 1786 in Carniola (Kranjska) Balthasar (Belsazar) Hacquet (1739-1815), born in France, physician and naturalist, was the contemporary of A. Fortis. He was a great traveller and researcher of mountains, from the Western Alps to the Carpathians. He visited a part of Dinaric Karst too, which was not in the Ottoman Empire (Južnič \& Kranjc 2013). About this travel he published »Physikalisch-Politische Reise Aus den Dinarischen durch die Julischen, Kärnischen, Rheti- schen, in die Norischen Alpen im Jahren 1781 und 1783 unternommen von Hacquet« (Physical-political travel from Dinaric Alps through Julian, Carnian, and Rhaetian Alps, to the Norican Alps, made by Hacquet in the years 1781 and 1783) (Hacquet 1785). As he said in the first chapter of this work: »Dinarische Alpen or Alpes Dinarii is partly limited by the Adriatic Sea. Otherwise this is a very long mountain chain from the Carpathians on the other side of the Danube river over Rila, including the Balkan (Stara Planina or Hemus), Rhodopes and Dinaric Mountains (in modern sense, note of the authors) to the Julian Alps. These Dinaric Alps are composed of mountains with proper names like Vlashitcha, Snessnize, Peesheviche and Vellebiche Planine. All of this great part of land is inhabited by Illyrians, Slavs, and Turks, all of them speaking Illyrian language. In their language these mountains are called Dinarizze Planine that is Dinarrische Alpen". According to Hacquet, the mountain got its name mostly because its shape; looking from the South-West it is round and Illyrians compared it with a coin because in their language "dinari" meant a round coin. As the second he thought that the name has the origin in the antique form of the name of the mountain that is Adrius. As he wrote: "Many of Illyrian writers omit the first vowel of a word." As the proof that it is correct to call these mountains a mountain chain he quotes Pomponius Mela who wrote that the whole mountain chain across the Thrace is known as Alpes.

\section{CONCLUSIONS}

During the $19^{\text {th }}$ century it looks that names Dinaric Alps and Dinaric Mountains were generally accepted and commonly used. As an example we are quoting one of the best known and generally used geographical description of the World of the author Malte-Brun (1828) that is Universal Geography where "Dinarian Alps" are described. Kozzen's Geographical Atlas (Heiderich \& Schmidt 1912) first published in 1861, atlas the most used in Austrian schools and even today, shows on maps "Dinarische Alpen « and the summit of it called »Dinara«. In 1869 the "Atlant" (Perko et al. 2005) was issued by Slovenska Matica, the first atlas in the Slovene language. On maps of this atlas figured both "Dinara Gora" (D. Mountain) and "Dinarske planine" (D. Mountains). The entry "Dinara" in popularly used Meyers Konverssations-Lexikon (1875) included »Dalmatischen « (Dalmatian) or "Dinarischen Alpen« (Dinaric Alps). From the same period is "Prirodni zemljopis Hrvatske" (Natural Geography of Croatia) by V. Klaić (1878) where both ex- pressions are used "Dinarske planine" (plural) and "Dinara planina” (singular).

In his early publications Jovan Cvijić did not use the name Dinaric Karst, but Dinaric System instead (Cvijić, 2000 a). Example is his first publication "Karst" from 1893 (Cvijić 1893). For him, the main part of Dinaric Karst as we see it nowadays was a part of Adriatic (Jadranski) Karst (Cvijić, 2000). Later he used expressions like "Dinarski holokarst" (Dinaric Holokarst) (Cvijić 2000 b) and "Le Holokarst dinarique" (Cvijić 1960). At the time when he published "Das Karstphänomen" (1893) the term Dinaric Alps was currently used in geographic as well as in popular works. The example is C. R. v. Steeb and K. Kandelsdorfer, reported by Cvijić (Cvijić, 2000 c). Relatively late, in 1927, Cvijić published the work "Dinarski karst” (Dinaric Karst) (Cvijić, 1927). It is difficult to rate Cvijić's influence upon knowledge and propagation of the name Dinara. In any case he is the most important to acquaint professional com- 
munity with the Dinaric karst as a toponym for a karst in general. Nowadays names as Dinara and Dinarsko gorje (Enciklopedija Jugoslavije 1956), Dinara Planina, Dinarskie Alpi, Dinarskoe nagorje (Kratkaya geograficheskaya enciklopedija 1961), Dinaridi, Dinarski kras, Dinarsko gorstvo (Enciklopedija Slovenije 1988),
Dinaric Alps, Dinarsko Gorje, and Dinara Planina (Encyclopaedia Britannica) figure in all important encyclopaedias, lexicons and geographical vocabularies (Oehlmann 1908). But still a lot of work and research is waiting scholars to explain the etymology and to find first apparitions of the name Dinara on maps.

\section{ACKNOWLEDGMENT}

We are thankful to Prof. Dražen Perica, Zadar University, Karst and Coast Research Centre, for his precious help.

\section{REFERENCES:}

Anon., 1903: The Geography of Strabo (literally translated, with notes, in three volumes). George Bell \& Sons, London.

Armanda, I. et al., 2017: Konstantin VII. Porfirogenet. In: Ravlić, S. Hrvatska enciklopedija, mrežno izdanje. Zagreb: Leksikografski zavod Miroslav Krleža. Available at: <http://enciklopedija.hr/Natuknica. aspx?ID=32883>.

Cvijić, J., 1893: Das Karstphänomen.- Geogr. Abhandl, 5,3, 218-329.

Cvijić, J., 1960: La Géographie des terrains calcaires.Monographies, T. CCCXLI. Académie Serbe des Sciences et des Arts, pp. 212, Beograd.

Cvijić, J., 2000: Karst, geografska monografija.- Sabrana dela, knj. 1, Srpska akademija nauka i umetnosti, 203-323, Beograd.

Cvijić, J., 2000a: Geomorfologija I. - Sabrana dela, knj. 6, Srpska akademija nauka i umetnosti, pp. 568, Beograd.

Cvijić, J., 2000b: Geografija krasa. - Sabrana dela, knj. 7, Srpska akademija nauka i umetnosti, pp. 279, Beograd.

Cvijić, J., 2000c: Podela planina na Balkanskom poluostrovu. - Sabrana dela, knj. 5, Srpska akademija nauka i umetnosti, 142-144, Beograd.

Cvijić, J., 1927: Dinarski karst. - Atlas Geografskog društva, 13, 17-29, Beograd.

Cvitanović, A., 2002: Geografski rječnik.- Hrvatsko geografsko društvo Zadar, pp. 685, Zadar.

Džino, D., 2010: Becoming Slav, becoming Croat: Identity transformations in post-Roman and early medieval Dalmatia.- Brill, pp. 271, London.

Enciklopedija Jugoslavije. 2, pp. 716, Leksikografski zavod FNRJ, Zagreb, 1956.
Enciklopedija Slovenije, 2, pp. 416, Mladinska knjiga, Ljubljana, 1988.

Evlija, Č., 1996: Putopis, Odlomci o jugoslovenskim zemljama.- Sarajevo-Publishing, pp. 704, Sarajevo.

Fortis, A., 2004: Put po Dalmaciji.- Marjan tisak, pp. 299, Split.

Hacquet, B., 1785: Physikalisch-Politische Reise. Aus den Dinarischen durch die Julischen, Kärnischen, Rhetischen, in die Norischen Alpen im Jahren 1781 und 1783 unternommen von Hacquet I-II.- A.F. Böhme, pp. $156+220$, Leipzig.

Hacquet, B., 1789: Oryctographia Carniolica oder Physikalische Erdbeschreibung des Herzogthums Krain ..., Vierter Theil.- J. G. I. Breitkopf, pp. 91, Leipzig.

Hamilton, H. C. \& W. Falconer, 1903: The Geography of Strabo. Literally translated, with notes, in three volumes.- George Bells \& Sons, pp. 1867, London.

Heiderich, F. \& W. Schmidt, 1912: Kozzens Geographischer Atlas.- Hölzel, Wien.

Južnič, S. \& A. Kranjc, 2013: Bibliography of Balthazar Hacquet (1739-1815) and his contribution to natural sciences.- ZRC Publishing, pp. 113, Ljubljana.

Klaić, V., 1878: Prirodni zemljopis Hrvatske.- Matica Hrvatska, pp. 406, Zagreb.

Kratkaya geograficheskaya enciklopedija. 2, pp. 592, Sovetskaya enciklopedija, Moskva, 1961.

Malte-Brun, M, 1828: Universal Geography. Vol. VI.Wells et al., pp. 699, Boston.

Meyers Konverssations-Lexikon. Fünfter Band, Dritte Auflage, pp. 1030, Bibliografische Institut, Leipzig 1875.

Oehlmann, E., 1908: E. von Seydlitz Handbuch der Geographie.- F. Hirt, pp. 844, Breslau.

Ortelius, A., 1590: Pannoniae et Illyrici veteris tabula.Antverpiani. 
Ostrogorski, G., 1969: History of the Byzantine state.Rutgers University Press, pp. 624, New Jersey.

Palma, G., 1812: Carte des Provinces Illyriennes.- Trieste. Perko, D., Šumrada, J., Orožen Adamič, M., Urbanc, M., Fridl, J. \& D. Kladnik, 2005: Atlant.- ZRC Publishing, Ljubljana.

Rogić, V., 1956: Dinara. Enciklopedija Jugoslavije, 2 (Bosna-Dio).- Leksikografski zavod FNRJ, pp. 707, Zagreb.

Roksandić, D., 1999-2000: Dinara kao ekohistorijski problem - ranovjekovni kartografski aspekti. Radovi.- Zavod za hrvatsku povijest, Vol. 32-33, Zagreb.
Šišić, F., 2004: Povijest Hrvata.- Marjan tisak, pp. 271, Split.

Skok, P., 1971: Etimologijski rječnik hrvatskoga ili srpskoga jezika, Knj. I. (A-J).-JAZU, pp. 691, Zagreb.

Stih, P., 2012: Becoming Slav, Becoming Croat. Identity Transformations in Post-Roman and Early Medieval Dalmatia.- Zgodovinski Casopis, 3, 4, 444-445.

Talbert, R.A., 2010: Peutinger map: seamless whole, in color, with overlaid layers.-Cambridge University Press.

Zoranić, P., 1988: Planine.- Grafički zavod Hrvatske, pp. 280, Zagreb. 